\title{
Antioxidative and angiotensin I-converting enzyme inhibitory activities of Eastern eel (Anguilla japonica)
}

\author{
Bethelehem Abebe ${ }^{1}$, Jun Ho Park ${ }^{1}$, Sang-Eun Pyo ${ }^{1}$, Ashagrie Gibtan ${ }^{1,2}$, \\ Sun-Mee Park ${ }^{3}$, Jae-Suk Choi ${ }^{1}$, Mi-Ryung Kim ${ }^{1 *}$ \\ ${ }^{1}$ Major in Food Biotechnology, Division of Bioindustry, Silla University, Busan 46958, Korea \\ ${ }^{2}$ Agriculture Modernization and Rural Development Center, Policy Study Institute of Ethiopia, 2479, Addis Ababa, Ethiopia \\ ${ }^{3}$ Department of Biotechnology, Pukyong National University, Busan 48513, Korea
}

\section{민물장어의 항산화 활성과 안지오텐신 I 전환효소 저해 효과}

\author{
베틀레헴 아베베 ${ }^{1} \cdot$ 박준호 $^{1} \cdot$ 표상은 $^{1}$ - 아샤그리 깁탄 ${ }^{1,2} \cdot$ 박선미 $^{3} \cdot$ 최재석 ${ }^{1} \cdot$ 김미령 $^{1 *}$ \\ ${ }^{1}$ 신라대학교 바이오산업학부 식품공학전공, ${ }^{2}$ 이디오피아 정책연구소, 이디오피아, \\ 3부경대학교 생물공학과
}

\begin{abstract}
This study was designed to investigate the antioxidative and angiotensin I-converting enzyme (ACE) inhibitory activities of Eastern eel (Anguilla japonica). Hot water extracts were prepared over a period of $25 \mathrm{~h}$ at $100^{\circ} \mathrm{C}$ from the meat and whole body of the Eastern eel. Protein hydrolysates of Eastern eel were prepared over a period of $10 \mathrm{~h}$ using different hydrolytic enzymes, such as Alcalase ${ }^{\circledR}$, Protamex ${ }^{\circledR}$, and Alcalase ${ }^{\circledR}+$ Protamex $^{\circledR}$. The antioxidative and ACE inhibitory activities of the eel hydrolysates were higher than those of the extracts, and showed similar trends for hydrolysis time on each assay system due to similar enzyme specificity. The hydrolysates produced using Alcalase ${ }^{\circledR}$ exhibited the highest DPPH scavenging activity $\left(\mathrm{IC}_{50}=3.02 \mathrm{mg} / \mathrm{mL}\right)$, while the Protamex ${ }^{\circledR}$ hydrolysates exhibited the highest ABTS $\left(\mathrm{IC}_{50}=1.13 \mathrm{mg} / \mathrm{mL}\right)$, hydroxyl radical $\left(\mathrm{IC}_{50}=1.30 \mathrm{mg} / \mathrm{mL}\right)$, and hydrogen peroxide $\left(\mathrm{IC}_{50}=1.11 \mathrm{mg} / \mathrm{mL}\right)$ scavenging activities and $\mathrm{ACE}$ inhibitory activity $\left(\mathrm{IC}_{50}=110.37 \mu \mathrm{g} / \mathrm{mL}\right)$. These results revealed that the Eastem eel hydrolysates exhibited strong radicals (DPPH, ABTS, superoxide, hydroxyl, and hydrogen peroxide) scavenging properties and $\mathrm{ACE}$ inhibitory activity, indicating that they can be potentially used as functional food ingredients with potential to prevent oxidation and reduce blood pressure.
\end{abstract}

Key words : Eastern eel (Anguilla japonica), hydrolysate, extract, antioxidative activity, ACE inhibitory activity

\section{Introduction}

The Eastern eel (Anguillia japonica) is one of 19 species within the freshwater eel family Anguillidae. They are common across the world, especially in East and South East Asian countries, predominantly in South Korea, China, Japan,
Thailand, and Philippines (Seo et al., 2013). They are used in many different ways including consuming as food and using in traditional Chinese medicine to cure skin diseases (e.g., atrophoderma) and hemorrhoids (Ekanayake et al., 2005). It is well known that fish and fishery products represent a valuable source of nutrients of fundamental

\footnotetext{
*Corresponding author. E-mail : haha7kmr@silla.ac.kr, Phone : +82-51-999-5873, Fax : +82-51-999-5873

Received 25 August 2020; Revised 15 October 2020; Accepted 19 October 2020.

Copyright (c) The Korean Society of Food Preservation.

This is an Open Access article distributed under the terms of the Creative Commons Attribution Non-Commercial License (http://creativecommons.org/licenses/by-nc/4.0) which permits unrestricted non-commercial use, distribution, and reproduction in any medium, provided the original work is properly cited.
} 
importance for diverse and healthy diets. Fish provides high-value protein, polyunsaturated omega-3 fatty acids (docosahexaenoic acid and eicosapentaenoic acid), and a wide range of essential micronutrients, including various vitamins ( $\mathrm{D}, \mathrm{A}$, and $\mathrm{B})$, minerals (e.g., calcium, iodine, zinc, iron, and selenium) (FAO, 2012). In addition to their high nutritious value, studies have been identified fish meat as a rich source of bioactive peptides with potentially valuable nutraceutical and pharmaceutical properties (Elavarasan et al., 2014; Halim et al., 2016). Bioactive peptides could be released from inactive original protein by enzymatic hydrolysis. These fish protein-derived bioactive peptides exhibit various biological activities such as antioxidative, anti-diabetic activities, anti-hypertensive, anti-coagulant, anti-proliferative, anti-obesity, and calcium-binding (Ngo et al., 2012). Moreover, it has been demonstrated that protein hydrolysates exhibiting antioxidative potential may contain peptides with other biological activities such as angiotensin I-converting enzyme (ACE) inhibitory activity (Samaranayaka et al., 2010).

Antioxidants are very important to human health. They can inhibit the oxidation reaction that cause cell damage or death in human body by removing free radical intermediates. Therefore, it is believed that antioxidants can decrease the risk of developing more than 100 diseases, including diabetes, heart disease, cancer, HIV (AIDS), stroke, and atherosclerosis, and then can slow the aging process (Ekanayake et al., 2005). Many natural antioxidants originating from plant and fish sources have been identified as free radical active scavengers (Clarke et al., 2013; Elavarasan et al., 2014; Mandal et al., 2009; Zhou et al., 2012). Hypertension, a long-term medical condition in which the blood pressure in the arteries is persistently elevated, is a major risk factor for cardiovascular disease. ACE plays a vital physiological role in the regulation of blood pressure. ACE cleaves angiotensin I to the potent vasoconstrictor angiotensin II and inactivates the vasodilator bradykinin (Ghanbari el al., 2015). These functions of ACE increase blood pressure and finally lead to hypertension. In addition, angiotensin II produced by ACE increases oxidative stress, inducing the production of reactive oxygen species (ROS) under high blood pressure conditions (Schiffrin and Touyz, 2004). Therefore, the inhibition of ACE activity or the blockade of angiotensin II formation may enhance the antioxidative system

A number of studies have reported the presence of bioactivities in enzymatically hydrolyzed fish proteins from salmon (Salmo salar) (Darewicz et al., 2014), rainbow trout (Oncorhynchus mykiss) (Kim and Byun, 2012), bigeye tuna (Thunnus obesus), dark muscle (Qian et al., 2007), and chum salmon (Oncorhynchus keta) (Ono et al., 2003). Recently, there are several published studies reporting the presence of bioactivities in enzymatically hydrolyzed Asian swamp eel (Monopterus sp.) proteins (Azemi et al., 2017; Baharuddin et al., 2016; Halim et al., 2017; Halim et al., 2018; Jamil et al. 2016). They report that Asian swamp eel protein hydrolysate using alcalase have the antioxidant activity (Azemi et al., 2017), ACE inhibitory activity (Azemi et al., 2017; Baharuddin et al., 2016) and anticancer activity (Halim et al., 2018). However, there was little known about the potential for multiple bioactivities of protein derived from Eastern eel (A. japonica). The main objective of the present study was to evaluate and compare the antioxidative potential and ACE inhibitory activity of enzymatic hydrolysates and hot water extracts of Eastern eel (A. japonica).

\section{Materials and methods}

\section{Chemicals}

Hydrogen peroxide $\left(\mathrm{H}_{2} \mathrm{O}_{2}\right)$, 1,1'-diphenyl-2-picrylhydrayl (DPPH), thiobarbaturic acid (TBA) and angiotensin Iconverting enzyme (ACE) were purchased from SigmaAldrich (St. Louis, MO, USA). Ethylene diamine tetra-acetic acid (EDTA), 2,2'-azino-bis (3-ethylbenzthiazolin)-6-sulfonic acid (ABTS), iron sulphate $\left(\mathrm{FeSO}_{4} \cdot 7 \mathrm{H}_{2} \mathrm{O}\right)$, peroxidase, 2-deoxyribose, monopotassium phosphate $\left(\mathrm{H}_{2} \mathrm{HPO}_{4}\right)$, potassium diphosphate $\left(\mathrm{KH}_{2} \mathrm{PO}_{4}\right)$, hydrochloric acid $(\mathrm{HCl})$, vitamin $\mathrm{C}$ and pyrogallol were purchased from Fluka Co. (St. Louis, MO, USA). All the other reagents used were either extra pure or analytical grade. Alcalase ${ }^{\circledR}$ (Alcalase 2.4L) and Promatex ${ }^{\circledR}$ were obtained from Novozymes (Copenhagen, Denmark).

\section{Fish protein extract and hydrolysate preparation}

Eastern eel (Anguilla japonica) were collected from local reservoirs (Chilbo-susan, Jeongeup, Korea), frozen immediately with the help of fishermen, and thawed rapidly below $35^{\circ} \mathrm{C}$ for analysis. The fish meat and the fish whole body 
of eel including the frame, dark muscle, cut offs, viscera, skin, scales, bones and fins, were collected for the hot water extraction of eel. These were minced and mixed with water in the ratio of 1:10 (fish mince: water). The extraction was done on $100^{\circ} \mathrm{C}$ with reflux, where samples were collected on different hours $(0,5,10,15,20$ and $25 \mathrm{~h})$. For the preparation of enzymatic hydrolysates, the fish meat was minced, mixed with the pre-warmed $0.1 \mathrm{M}$ sodium phosphate buffer $(\mathrm{pH} 7)$ in the ratio of 1:10 (fish mince: sodium phosphate buffer) and each protease was added as the final conc. of $1.15 \%$. The hydrolysis reaction was performed at $50^{\circ} \mathrm{C}$ for $10 \mathrm{~h}$. The hydrolysates were collected at 2 hours' interval $(0,2,4,6,8$ and $10 \mathrm{~h})$. The collected hydrolysates were inactivated in boiling water for $10 \mathrm{~min}$. After cooling at room temperature, each sample was clarified by centrifugation at $3,000 \mathrm{rpm}$ for $20 \mathrm{~min}$ to remove any residue and stored at $-20^{\circ} \mathrm{C}$. Hydrolysates were designated as ME-ALP (Alcalase ${ }^{\circledR}$ ), ME- PRH (Promatex ${ }^{\circledR}$ ) and ME-APH (Alcalase ${ }^{\circledR}+$ Promatex $^{\circledR}$ ) based on the enzyme used for hydrolysis. Hot water extracts based on the source for extraction, were expressed as ME (meat extract) and WBE (whole body extract).

\section{Chemical analysis}

Moisture and ash contents of Eastern eel (Anguilla japonica) were determined according to the AOAC (2005), standard methods 930.15 and 942.05 , respectively. Total nitrogen content was determined by using the Kjeldahl method according to AOAC (2005) method number 984.13. Crude protein was estimated by multiplying total nitrogen content by the factor 6.25. Crude fat was determined gravimetrically after Soxhlet extraction of samples with hexane. All measurements were performed in triplicate.

\section{Protein concentration determination}

The protein contents of the hot water extracts and hydrolysates were estimated by the Lowry assay (Lowry et al., 1951). According to this procedure, the samples were first pretreated with copper ions in an alkali solution. The aromatic amino acids in the treated samples reduced the phosphomolybdic-phosphotungstic acid present in the Folin reagent. Since the endpoint of the reaction has a blue color, the amount of protein in the sample were estimated by reading the absorbance using a spectrophotometer (Optizen
3220 UV-VIS spectrophometer, Daejeon, Korea) at $750 \mathrm{~nm}$. BSA was used as standard.

\section{Determination of DPPH radicals scavenging activity}

Determination of DPPH radicals scavenging activity was estimated with the modification of the methods used by Khan et al. (2012). A $100 \mu \mathrm{L}$ of $0.4 \mathrm{mM}$ DPPH solution and $100 \mu \mathrm{L}$ of the sample were added, mixed well in 96 microwell plates for 10-20 seconds and incubated for 30 min at room temperature in the dark. After incubation, the absorbance was measured at $540 \mathrm{~nm}$ against the corresponding blank solution (ethanol without the sample). The control was prepared by taking $100 \mu \mathrm{L}$ DPPH and $100 \mu \mathrm{L}$ of distilled water. Percentage inhibition of free radical DPPH was calculated based on following equation.

DPPH scavenging $(\%)=[(\mathrm{Ac}-\mathrm{As}) /(\mathrm{Ac}-\mathrm{Ab})] \times 100$.

Where Ac is the absorbance of control; As is the absorbance of mixture containing sample; $\mathrm{Ab}$ is the absorbance of blank.

\section{Determination of $A B T S$ radical-scavenging activity}

ABTS radical-scavenging activity was determined by ABTS assay as described by Binsan et al. (2008). The working solution was prepared by mixing the two stock solutions (7 $\mathrm{mM}$ ABTS solution and $2.45 \mathrm{mM}$ potassium persulfate) in equal quantities and allowing them to react for $12-16 \mathrm{~h}$ at room temperature in the dark. ABTS solution was then diluted by mixing distilled water to obtain an absorbance of 0.7-0.8 at $734 \mathrm{~nm}$ using a spectrophotometer (Optizen 3220 UV-VIS Spectrophotometer, Gyeonggi-do, Korea). $180 \mu \mathrm{L}$ ABTS solution and $20 \mu \mathrm{L}$ of the sample were mixed, left at room temperature for $2 \mathrm{~min}$ in the dark and read at 734 $\mathrm{nm}$. ABTS radical-scavenging activity was calculated by the following equation.

ABTS radical scavenging (\%)

$$
=[(\mathrm{Ac}-\mathrm{As}) /(\mathrm{Ac}-\mathrm{Ab})] \times 100
$$

Where Ac is the absorbance of control (ABTS and distilled water); As is the absorbance of mixture containing sample; $\mathrm{Ab}$ is the absorbance of blank (distilled water). 


\section{Superoxide $\left(\mathrm{O}_{2}^{-}\right)$scavenging assay}

Ability of the samples to inhibit the autoxidation of pyrogallol was done by modifying Marklund and Marklund (1974). Briefly, $0.3 \mathrm{~mL}$ of the sample and $2.65 \mathrm{~mL}$ of 50 $\mathrm{mM}$ phosphate buffer (pH 7.4 at $37^{\circ} \mathrm{C}$ ) containing $1 \mathrm{mM}$ $\mathrm{Na}_{2}$ EDTA were mixed in a cuvette. Freshly prepared $50 \mu \mathrm{L}$ of $60 \mathrm{mM}$ progallol in $1 \mathrm{mM} \mathrm{HCl}$ was added and the inhibition of pyrogallol autoxidation was measured at 325 $\mathrm{nm}$ using spectrophotometer. Absorbance of sample was recorded at $0 \mathrm{~min}$ and after $5 \mathrm{~min}$ and the increment of absorbance was calculated by the difference.

$\mathrm{O}_{2}^{-}$Scavenging activity $(\%)=[(\Delta \mathrm{Ac}-\Delta \mathrm{As}) / \Delta \mathrm{Ac}] \times 100$

Where $\Delta \mathrm{As}$ is the absorbance increment of the mixture containing the sample and $\Delta \mathrm{Ac}$ is absorbance increment of the mixture without the sample.

\section{Hydroxyl radical $(\cdot \mathrm{OH})$ scavenging assay}

The $\cdot \mathrm{OH}$ scavenging activity was determined by modified methods of Chung et al. (1997). A $100 \mu \mathrm{L}$ sample and 500 $\mu \mathrm{L}$ of $0.1 \mathrm{M}$ phosphate buffer ( $\mathrm{pH}$ 7.4) were mixed with $100 \mu \mathrm{L}$ of $10 \mathrm{mM} \mathrm{FeSO}_{4}, 100 \mu \mathrm{L}$ of $10 \mathrm{mM}$ EDTA and $100 \mu \mathrm{L}$ of $10 \mathrm{mM}$ 2-deoxyribose in order to make a total volume of $900 \mu \mathrm{L}$, then $100 \mu \mathrm{L}$ of $10 \mathrm{mM}$ of $\mathrm{H}_{2} \mathrm{O}_{2}$ were added, and incubated at $37^{\circ} \mathrm{C}$ for $4 \mathrm{~h}$. After incubation, 0.5 $\mathrm{mL}$ of $2.8 \%$ TCA and $0.5 \mathrm{~mL}$ of $0.1 \%$ TBA dissolved in water were added to the reaction mixture and kept in a boiling water bath for $10 \mathrm{~min}$. The absorbance was measured at $532 \mathrm{~nm}$.

Hydroxyl radical scavenging $(\%)=[(\mathrm{Ac}-\mathrm{As}) / \mathrm{Ac}] \times 100$

Where Ac is the absorbance of mixture without sample; As is the absorbance of mixture containing sample.

\section{Hydrogen peroxide $\left(\mathrm{H}_{2} \mathrm{O}_{2}\right)$ scavenging assay}

The $\mathrm{H}_{2} \mathrm{O}_{2}$ scavenging activity was determined according to the method of Muller (1985). The $20 \mu \mathrm{L}$ of sample was dissolved in $100 \mu \mathrm{L}$ of $0.1 \mathrm{M}$ phosphate-buffered saline $(\mathrm{pH}$ 5.0), mixed with $20 \mu \mathrm{L}$ of $10 \mu \mathrm{mM} \mathrm{H}_{2} \mathrm{O}_{2}$, and incubated at $37^{\circ} \mathrm{C}$ for $5 \mathrm{~min}$. Then, $30 \mu \mathrm{L}$ of $1.25 \mathrm{mM}$ ABTS and 30 $\mu \mathrm{L}$ of peroxidase ( 1 unit $/ \mathrm{mL}$ ) were added to the mixture and re-incubated at $37^{\circ} \mathrm{C}$ for $10 \mathrm{~min}$. The incubation of $\mathrm{ABTS}$ with peroxidase resulted in the production of the radical $\mathrm{ABTS}^{+}$, which is blue green and absorbance of each sample was measured at $405 \mathrm{~nm}$.

Hydrogen peroxide scavenging (\%)

$$
=[(\mathrm{Ac}-\mathrm{As}) / \mathrm{Ac}] \times 100
$$

\section{Angiotensin I-converting enzyme (ACE) inhibitory activity}

ACE inhibitory activity was measured according to the method described by Cushman and Cheung (1971) with some modification. This method was based on liberation of hippuric acid (HA) from hippuryl-1-histidyl-l-leucine (HipHis-Leu, HHL) catalyzed by the ACE. The sample $(25 \mu \mathrm{L})$ was pre-incubated with $50 \mu \mathrm{L}$ substrate solution $(8.3 \mathrm{mM}$ HHL in $50 \mathrm{mM}$ sodium borate buffer containing $0.5 \mathrm{M}$ $\mathrm{NaCl}$ at $\mathrm{pH} 8.3$ ) at $37^{\circ} \mathrm{C}$ for $10 \mathrm{~min}$. The reaction started by adding $50 \mu \mathrm{L}$ of pre-heated ACE $(8 \mathrm{mU})$ solution in sodium borate and the mixture was incubated for $30 \mathrm{~min}$ at $37^{\circ} \mathrm{C}$. The reaction was stopped by addition of $125 \mu \mathrm{L} 1 \mathrm{~N}$ $\mathrm{HCl}$. The formed HA was extracted with $750 \mu \mathrm{L}$ ethyl acetate and centrifuged (3,000 rpm, $15 \mathrm{~min})$. The organic phase $(500 \mu \mathrm{L})$ was evaporated at $50^{\circ} \mathrm{C}$ for $4 \mathrm{~h}$. The dried residue was dissolved in $750 \mu \mathrm{L}$ of pre- heated water $\left(60^{\circ} \mathrm{C}\right)$, vortexed for $5 \mathrm{~min}$ and the absorbance was read at $228 \mathrm{~nm}$ in a spectrophotometer (Optizen 3220 UV-VIS spectrophotometer, Korea). The extent of ACE inhibition was calculated using the following formula:

$\mathrm{ACE}$ Inhibition $(\%)=[(\mathrm{Ac}-\mathrm{As}) /(\mathrm{Ac}-\mathrm{Ab})] \times 100$

Where Ac is the absorbance of control (HHL and ACE), As is mixture containing sample, and $\mathrm{Ab}$ is blank (distilled water). The antihypertensive agent, captopril was used as a standard.

\section{Amino acid composition analysis}

The sample preparation was carried out by hydrolysis with $6 \mathrm{M} \mathrm{HCl}$ at $110^{\circ} \mathrm{C}$ for $24 \mathrm{~h}$ and derivated by using phenyl isothiocyanate prior to HPLC analysis. The total amino acids compositions were analyzed by an automated amino acid analyzer (L-8900; Hitachi High-Technologies Corp., Tokyo, Japan). 


\section{Statistical analysis}

All tests were conducted in triplicates. All results were expressed as mean $\pm \mathrm{SD}$. The data was statistically analyzed by one-way ANOVA followed by Duncan's multiple range tests using SPSS package program (Version 26, IBM SPSS statistics, Armonk, NY, USA). p-value less than 0.05 were considered statistically significant.

\section{Results}

\section{Chemical composition of Eastern eel}

According to the chemical composition results, Eastern eel contains $61.8 \%$ moisture, $14.8 \%$ protein, $20.7 \%$ fat, $1.5 \%$ ash, and $1.2 \%$ carbohydrate. In particular, the fat and protein contents are very high in Eastern eel. Excluding the moisture content, the ratios of fat and protein were $54.2 \%$ and $38.7 \%$ on a dry basis.

\section{Production of Eastern eel extracts and protein hydrolysates}

To monitor the degree of protein extraction, the protein concentrations of ME and WBE were determined at intervals of $5 \mathrm{~h}$ over an extraction time of $25 \mathrm{~h}$ (Fig. 1A). The initial concentrations in the ME and WBE were 0.364 and $0.116 \mathrm{mg} / \mathrm{ml}$, respectively. The final protein concentrations in the ME and WBE were 5.08 and $6.87 \mathrm{mg} / \mathrm{mL}$, respectively, corresponding to 14.1- and 59.1-fold increases from the initial protein concentration, indicating that the protein yield of the WBE was higher than that of the ME. The protein concentration curves of the hydrolysates tended

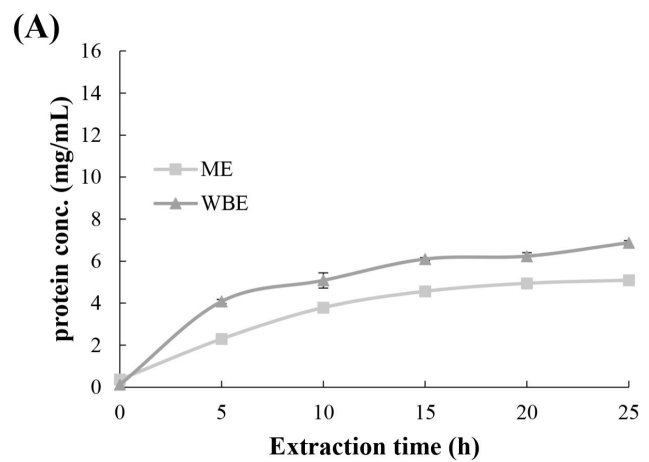

to have an initial rapid phase during the first $2 \mathrm{~h}$ followed by a phase of slow increase after the core proteins had been hydrolyzed (Fig. 1B). The initial average protein concentration of eel meat was $0.147 \mathrm{mg} / \mathrm{mL}$. The final protein concentrations in the ME-ALP, ME-PRH, and ME-APH were $10.6,11.22$, and $12.1 \mathrm{mg} / \mathrm{mL}$, respectively, corresponding to 71.9-, 76.3-, and 82.2-fold increases from the initial protein concentration for ME-ALP, ME-PRH, and ME-APH, respectively. All hydrolysates showed higher protein yields than the eel extracts. At the same concentration, the ME-APH showed greater proteolytic activity.

\section{DPPH radical scavenging activity}

While the ME and WBE at $25 \mathrm{~h}$ did not show DPPH radical scavenging activity, the ME-APH was found to have greater scavenging ability $(56.6 \%)$ followed by the ME-ALP $(47.0 \%)$ and ME-PRH (30.1\%) at $10 \mathrm{~h}$ (Fig. 2A; p<0.05). The changes in DPPH radical scavenging activity were monitored during the hydrolysis process, as shown in Fig. 2B. The highest level of activity in the ME-ALP was $57.0 \%$ at $2 \mathrm{~h}$; that in the ME-APH and ME-PRH was $59.9 \%$ and $48.1 \%$ after $8 \mathrm{~h}$ of hydrolysis, respectively.

\section{ABTS radical scavenging activity}

As shown in Fig. 2A, the ABTS radical scavenging activities of the ME and $\mathrm{WBE}$ were $55.5 \%$ and $57.5 \%$ at $25 \mathrm{~h}$, but they were not significantly different $(\mathrm{p}=0.169)$. All hydrolysates showed an ABTS radical scavenging power of $>98 \%$. ABTS radical scavenging activities higher than $50 \%$ were recorded after $15 \mathrm{~h}$ of extraction $(54.5 \%$ at $15 \mathrm{~h}$ for
(B)

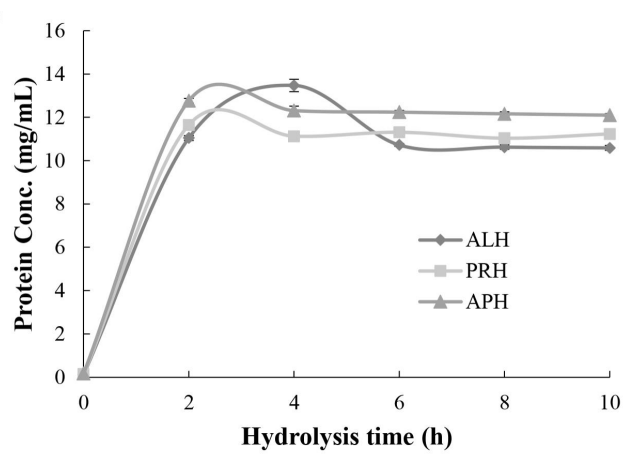

Fig. 1. Protein concentrations of hot water extracts (A) and enzyme hydrolysates (B) prepared from Eastem eel at different times. ME, meat extracts; WBE, whole body extracts ; ALP, Alcalase ${ }^{\circledR}$-treated hydrolysates (ME-ALP); PRH, Promatex ${ }^{\circledR}$-treated hydrolysates (ME-PRH); APH, the mixture of Alcalase ${ }^{\mathbb{B}}$ and Promatex ${ }^{\mathbb{B}}$-treated hydrolysates (ME-APH). 
(A)

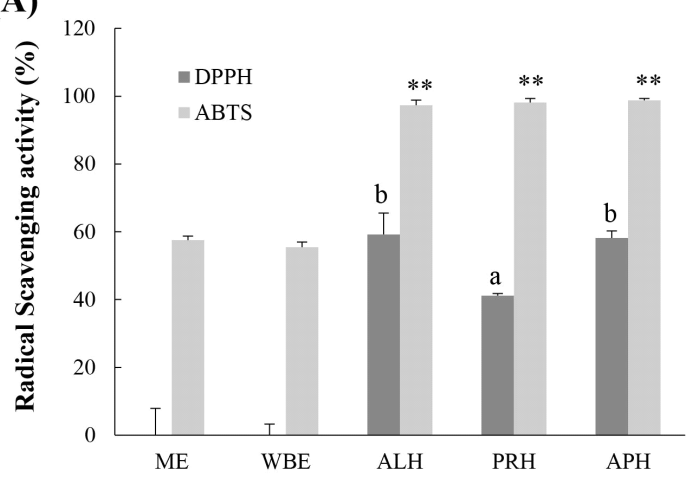

(C)

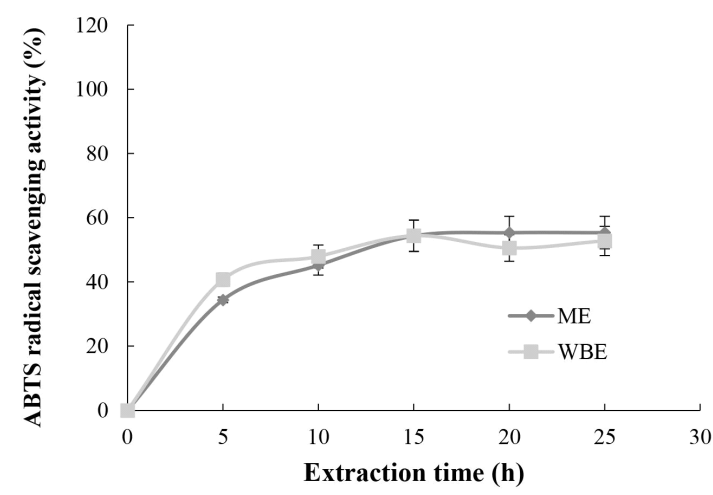

(B)
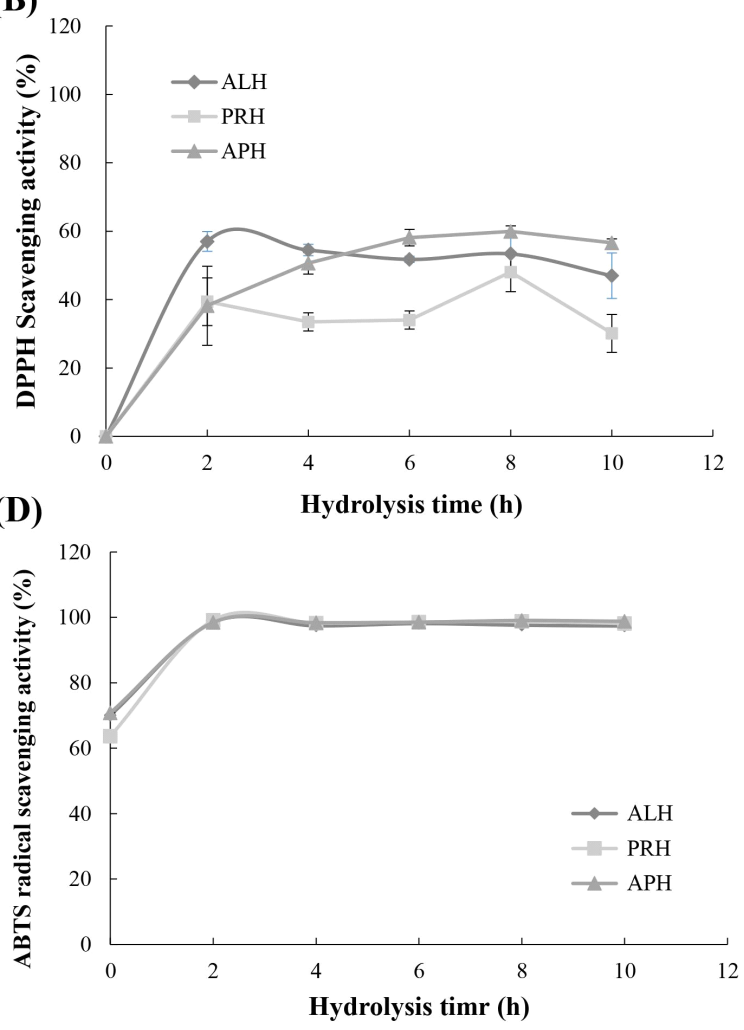

Fig. 2. DPPH and ABTS radical scavenging activities in hot water extracts and hydrolysates prepared from Eastem eel.

A, comparison of DPPH and ABTS radical scavenging activities at final extraction $(25 \mathrm{~h})$ and hydrolysis $(10 \mathrm{~h})$ times; B, DPPH radical scavenging activities of Eastern eel hydrolysates for $10 \mathrm{~h}$ hydrolysis times; C, ABTS radical scavenging activities of hot water extracts for $25 \mathrm{~h}$ extraction times; D, ABTS radical scavenging activities of Eastern eel hydrolysates for $10 \mathrm{~h}$ hydrolysis times.

ME, meat extracts; WBE, whole body extracts; ALP, Alcalase ${ }^{\circledR}$-treated hydrolysates (ME-ALP); PRH, Promatex ${ }^{\circledR}$-treated hydrolysates $(\mathrm{ME}-\mathrm{PRH})$; $\mathrm{APH}$, the mixture of Alcalase ${ }^{\mathbb{B}}$ and Promatex ${ }^{\mathbb{B}}$-treated hydrolysates (ME-APH).

and the different letters in $\left({ }^{A}\right)$ mean significant difference $(p<0.01)$.

the ME and $55.4 \%$ at $20 \mathrm{~h}$ for the WBE; Fig. 2C), while all hydrolysates reached $>98 \%$ ABTS radical scavenging power at $2 \mathrm{~h}$. The ME-PRH (99.1\%) at $2 \mathrm{~h}$ had the highest level of activity, followed by the ME-APH (99.03\%) at 8 $\mathrm{h}$ and ME-ALP (98.50\%) at $2 \mathrm{~h}$ (Fig. 2D).

\section{Superoxide $\left(\mathrm{O}_{2}^{-}\right)$scavenging activity}

The highest $\mathrm{O}_{2}{ }^{-}$scavenging activities of the eel hot water extracts were recorded as $41.0 \%$ at $5 \mathrm{~h}$ for the ME and $28.7 \%$ at $20 \mathrm{~h}$ for the WBE (Fig. 3A), respectively. The $\mathrm{O}_{2}^{-}$ scavenging activity of the eel hydrolysates increased rapidly to $40 \%$ within $2 \mathrm{~h}$ of hydrolysis and slowly settled to approximately $65 \%$ at $10 \mathrm{~h}$. The $\mathrm{O}_{2}^{-}$scavenging activities of the hydrolysates at the end of hydrolysis $(10 \mathrm{~h})$ were recorded as $59.9 \%$ for the ME-ALP, $67.0 \%$ for the ME-PRH, and $64.5 \%$ for the ME-APH. The highest level of
$\mathrm{O}_{2}^{-}$scavenging activity was recorded at $10 \mathrm{~h}$ for the ME-PRH (67.00\%) (Fig. 3B).

\section{Hydroxyl radical $(\cdot \mathrm{OH})$ scavenging activity}

The greatest $\cdot \mathrm{OH}$ scavenging activities observed in the hot water extracts were $22.4 \%$ at $25 \mathrm{~h}$ and $21.5 \%$ at $15 \mathrm{~h}$ for the ME and WBE (Fig. 3C), respectively; those in the hydrolysates were $61.8 \%$ and $63.9 \%$ at $4 \mathrm{~h}$ for the ME-ALP and ME-PRH, and $68.0 \%$ at $6 \mathrm{~h}$ for the ME-APH (Fig. 3D).

\section{Hydrogen peroxide $\left(\mathrm{H}_{2} \mathrm{O}_{2}\right)$ scavenging activity}

The highest $\mathrm{H}_{2} \mathrm{O}_{2}$ scavenging activities were $47.4 \%$ at 10 $\mathrm{h}$ for the ME and $51.1 \%$ at $10 \mathrm{~h}$ for the WBE (Fig. 3E). The highest $\mathrm{H}_{2} \mathrm{O}_{2}$ scavenging activities in the hydrolysates were $52.6 \%$ after $4 \mathrm{~h}$ of hydrolysis for the ME-ALP, and 55.4\% and $53.8 \%$ at $8 \mathrm{~h}$ for the ME-PRH and ME-APH (Fig. 3F). 
(A)

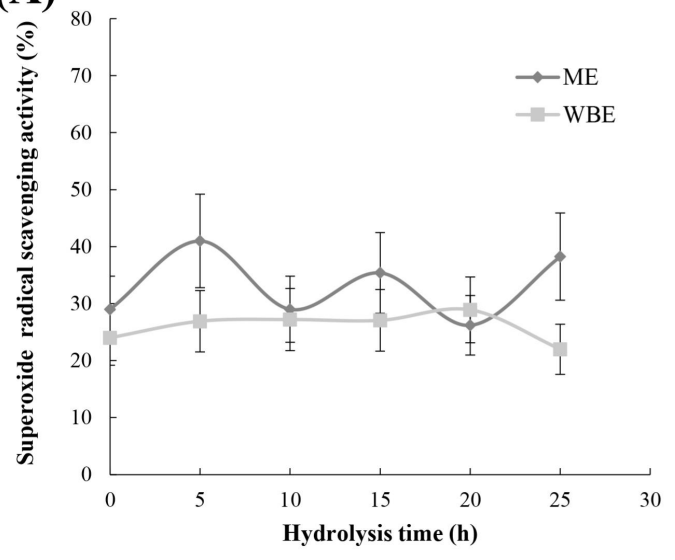

(C)

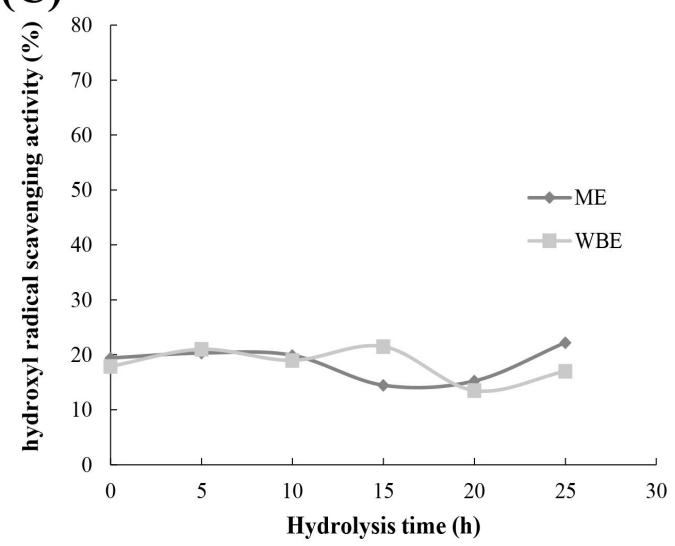

(E)

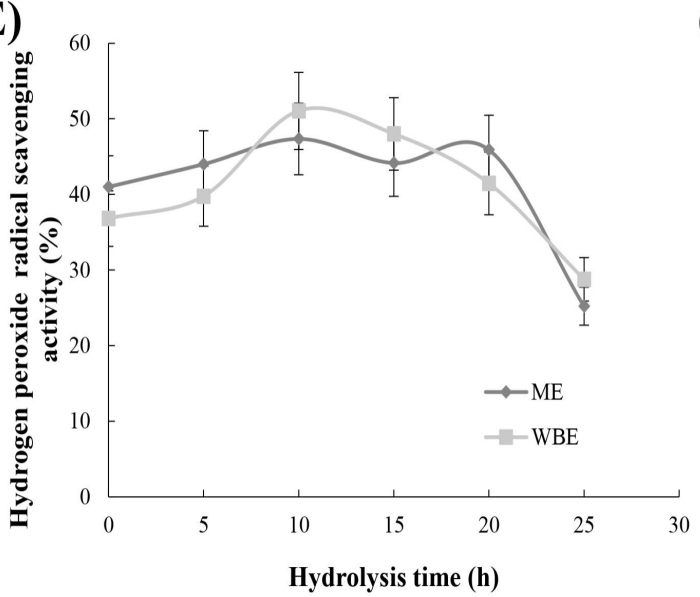

(B)

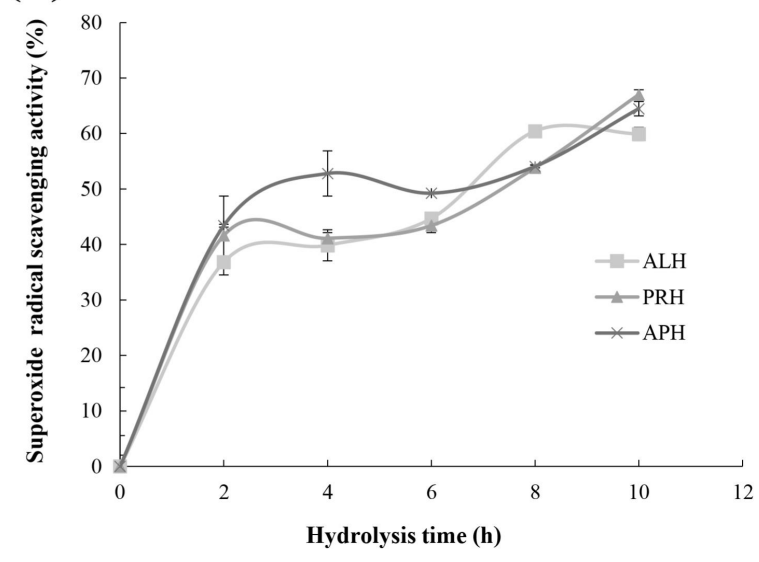

(D)

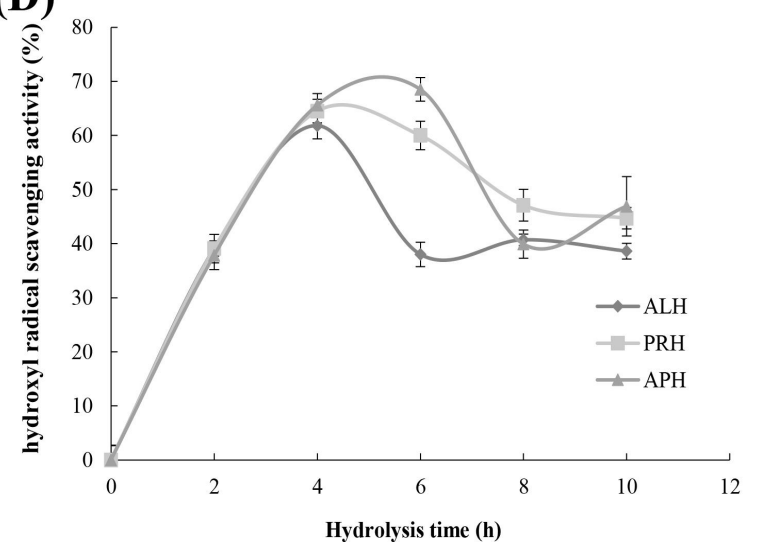

(F)

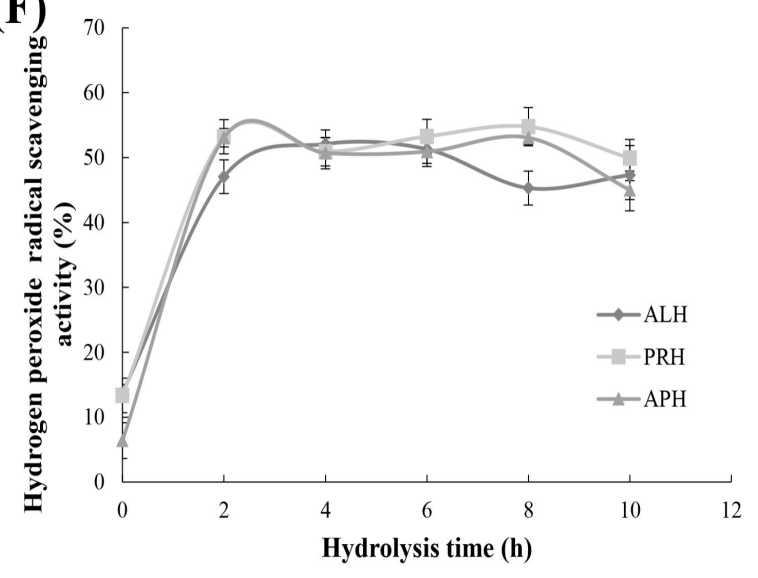

Fig. 3. Superoxide $\left(\mathrm{O}_{2}^{-}\right)$, hydroxyl radical $(\mathrm{OH})$, and hydrogen peroxide $\left(\mathrm{H}_{2} \mathrm{O}_{2}\right)$ scavenging activities in hot water extracts and hydrolysates prepared from Eastem eel at different hydrolysis times.

A, superoxide $\left(\mathrm{O}_{2}^{-}\right)$scavenging activities of hot water extracts; B, superoxide $\left(\mathrm{O}_{2}^{-}\right)$scavenging activities of hydrolysates; $\mathrm{C}$, hydroxyl radical $(\cdot \mathrm{OH})$ radical scavenging activities of hot water extracts; $\mathrm{D}$, hydroxyl radical $(\cdot \mathrm{OH})$ radical scavenging activities of hydrolysates; $\mathrm{E}$, hydrogen peroxide $\left(\mathrm{H}_{2} \mathrm{O}_{2}\right)$ scavenging activities of hot water extracts; $\mathrm{F}$, hydroxyl $(\bullet \mathrm{OH})$ radical scavenging activities of hydrolysates.

ME, meat extracts; WBE, whole body extracts; ALP, Alcalase ${ }^{\mathbb{B}}$-treated hydrolysates (ME-ALP); PRH, Promatex ${ }^{\mathbb{B}}$-treated hydrolysates (ME-PRH); $\mathrm{APH}$, the mixture of Alcalase ${ }^{\mathbb{B}}$ and Promatex ${ }^{\mathbb{B}}$-treated hydrolysates (ME-APH). 


\section{$\mathrm{IC}_{50}$ values showing antioxidative activities of eel protein hydrolysates}

The hydrolysates showed similar trends in the DPPH radical, ABTS radical, $\mathrm{O}_{2}^{-}, \cdot \mathrm{OH}$, and $\mathrm{H}_{2} \mathrm{O}_{2}$ scavenging assays in terms of their biological activities. Thus, the $\mathrm{IC}_{50}$ values (concentration required to scavenge $50 \%$ of radical, anion, or $\mathrm{H}_{2} \mathrm{O}_{2}$ ) of the hydrolysates (10 h) were compared in each assay. Ascorbic acid and $\alpha$-tocopherol were used as positive controls. As shown in Table 1 , the lowest $\mathrm{IC}_{50}$ value of DPPH was $2.73 \mathrm{mg} / \mathrm{mL}$ in the ME-ALP; that of $\alpha$-tocopherol was $0.36 \mathrm{mg} / \mathrm{mL}$. However, the lowest $\mathrm{IC}_{50}$ values from the ABTS scavenging activity assay was found in the ME-PRH with $1.13 \mathrm{mg} / \mathrm{mL}$. The lowest $\mathrm{IC}_{50}$ values from the ${ }^{\circ} \mathrm{OH}$ and $\mathrm{H}_{2} \mathrm{O}_{2}$ scavenging activity assays were also found in the ME-PRH, at 1.11 , and $1.3 \mathrm{mg} / \mathrm{mL}$, respectively. The $\mathrm{IC}_{50}$ values of $\mathrm{O}_{2}^{-}$scavenging activity were $3.01,3.07$, and 3.14 mg for the ME-ALP, ME-PRH, and ME-APH, respectively, which are not significantly different. The $\mathrm{IC}_{50}$ value of ascorbic acid was $0.22 \mathrm{mg} / \mathrm{mL}$ for ABTS radical scavenging activity, $0.31 \mathrm{mg} / \mathrm{mL}$ for $\mathrm{H}_{2} \mathrm{O}_{2}$ radical scavenging activity, and $0.42 \mathrm{mg} / \mathrm{mL}$ for $\cdot \mathrm{OH}$ scavenging activity. The ME-PRH exhibited the highest ABTS, ${ }^{\circ} \mathrm{OH}$, and $\mathrm{H}_{2} \mathrm{O}_{2}$ scavenging activities, while the ME-ALP exhibited the highest DPPH scavenging activity.

\section{ACE inhibitory activity of eel extracts and hydrolysates}

The ACE inhibitory activities of the hot water extracts at $25 \mathrm{~h}$ were $8.6 \%$ for the ME and $0 \%$ for the WBE, while those of the hydrolysates at $10 \mathrm{~h}$ were approximately $75 \%$ for all hydrolysates $(72.6 \%$ for the ME-ALP, $75.7 \%$ for the
ME-PRH, and $75 \%$ for the ME-APH; Fig. 4A). The ACE inhibitory activities of the hydrolysates at $10 \mathrm{~h}$ of hydrolysis were not significantly different $(p=0.108)$. The ACE inhibitory activities of the hydrolysates showed an initial rapid increase during the first $2 \mathrm{~h}$ of hydrolysis and then maintained a similar activity for all hydrolysates. The highest activity levels were $74.79 \%(8 \mathrm{~h})$ for the ME-ALP, $78.30 \%(8 \mathrm{~h})$ for the ME-PRH, and $80.42 \%(2 \mathrm{~h})$ for the ME-APH (Fig. 4B). To characterize the ACE inhibitory activity of the hydrolysates further, $\mathrm{IC}_{50}$ values for $\mathrm{ACE}$ inhibition of the hydrolysates were determined as shown in Table 1. The $\mathrm{IC}_{50}$ values for the ME-ALP, ME-PRH, and ME-APH were 132.91, 110.37, and $115.17 \mu \mathrm{g} / \mathrm{mL}$, respectively $(\mathrm{p}=0.164)$. The $\mathrm{IC}_{50}$ value for captopril, a synthetic ACE inhibitor (positive control), was $0.0567 \mu \mathrm{g} / \mathrm{mL}$. Similar to the results for antioxidative activity, the greatest ACE inhibitory activity was found in the ME-PRH, although the values were not significantly different among the hydrolysates.

\section{Amino acid composition of eel extracts and hydrolysates}

The amino acid composition of eel meat extract and hydrolysates were compared in Table 2 . The contents of glycine and alanine were to approximately $37 \%$ and the ratio of hydrophobic amino acids to total amino acids was 0.2081 on ME. On three hydrolysates of Eastern eel, the contents of leucine, valine and tyrosine, which were hydrophobic amino acids, were increased more than 2 times and glycine and alanine were decreased to 8.46 and $8.56 \%$, respectively. The ratios of hydrophobic amino acids to total

Table 1. IC $_{50}$ values of Eastem eel hydrolysates on various antioxidative and ACE inhibitory assay systems

\begin{tabular}{ccccccc}
\hline Hydrolysates & $\begin{array}{c}\mathrm{DPPH} \\
(\mathrm{mg} / \mathrm{mL})\end{array}$ & $\begin{array}{c}\mathrm{ABTs} \\
(\mathrm{mg} / \mathrm{mL})\end{array}$ & $\begin{array}{c}\text { Superoxide } \\
(\mathrm{mg} / \mathrm{mL})\end{array}$ & $\begin{array}{c}\text { Hydrogen peroxide } \\
(\mathrm{mg} / \mathrm{mL})\end{array}$ & $\begin{array}{c}\text { Hydroxyl } \\
(\mathrm{mg} / \mathrm{mL})\end{array}$ & $\begin{array}{c}\text { ACE inhibitory } \\
(\mu \mathrm{g} / \mathrm{mL})\end{array}$ \\
\hline ME-ALP & $2.73 \pm 0.02^{\mathrm{al})}$ & $1.28 \pm 0.08^{\mathrm{c}}$ & $3.01 \pm 0.05$ & $1.83 \pm 0.017^{\mathrm{b}}$ & $1.37 \pm 0.00^{\mathrm{b}}$ & $132.91 \pm 17.31$ \\
ME-PRH & $3.02 \pm 0.03^{\mathrm{b}}$ & $1.13 \pm 0.02^{\mathrm{a}}$ & $3.07 \pm 0.05$ & $1.11 \pm 0.00^{\mathrm{a}}$ & $1.30 \pm 0.00^{\mathrm{a}}$ & $110.37 \pm 12.85$ \\
ME-APH & $3.21 \pm 0.01^{\mathrm{c}}$ & $1.17 \pm 0.00^{\mathrm{b}}$ & $3.14 \pm 0.03$ & $1.85 \pm 0.00^{\mathrm{b}}$ & $1.61 \pm 0.00^{\mathrm{c}}$ & $115.17 \pm 4.48$ \\
\hline Ascorbic acid & $-^{2)}$ & $0.22 \pm 0.03$ & - & $0.31 \pm 0.03$ & $0.42 \pm 0.04$ & - \\
$\alpha$-Tocopherol & $0.36 \pm 0.01$ & - & $0.41 \pm 0.08$ & - & - & - \\
Captopril & & & & & & $0.06 \pm 0.01$ \\
\hline
\end{tabular}

${ }^{1)} \mathrm{Mean} \pm \mathrm{SD}(\mathrm{n}=3)$ within each column followed by different letters are significantly different $(\mathrm{p}<0.05)$.

${ }^{2)}$ Not tested. 

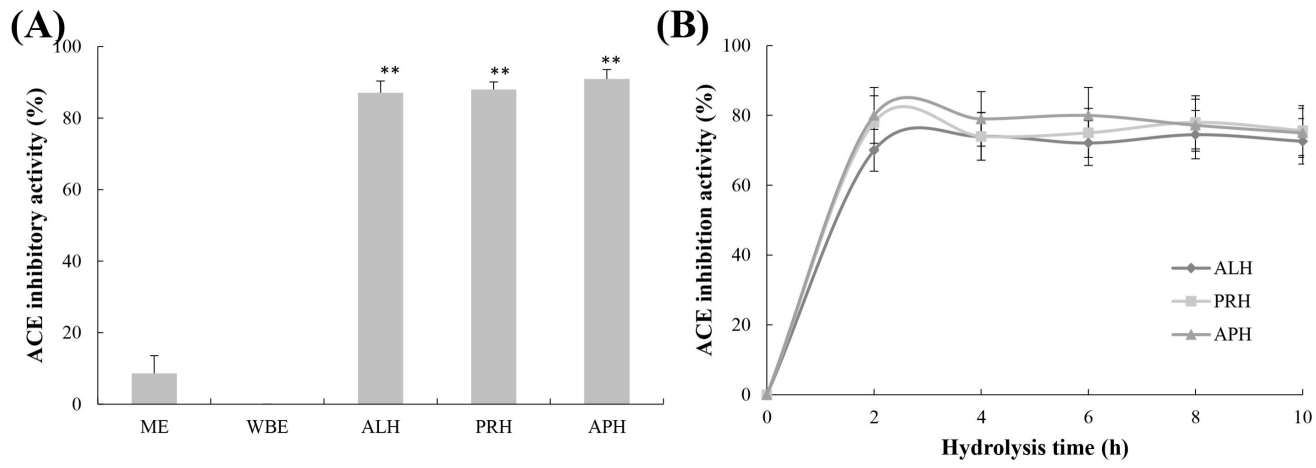

Fig. 4. Comparison of ACE inhibitory activities of Eastern eel extracts and hydrolysates.

A, ACE inhibitory activities of Eastern eel at final extraction $(25 \mathrm{~h})$ and hydrolysis $(10 \mathrm{~h})$ time; B, ACE inhibitory activities of Eastern eel hydrolysates prepared by different enzymes for $10 \mathrm{~h}$ hydrolysis times.

ME, meat extracts; WBE, whole body extracts; ALP, Alcalase ${ }^{\circledR}$-treated hydrolysates (ME-ALP); PRH, Promatex ${ }^{\circledR}$-treated hydrolysates (ME-PRH); $\underset{* *}{\mathrm{APH}}$, the mixture of Alcalase ${ }^{\circledR}$ and Promatex ${ }^{\circledR}$-treated hydrolysates (ME-APH).

means significant difference $(\mathrm{p}<0.01)$.

Table 2. The amino acid composition of eel extracts and hydrolysates

\begin{tabular}{|c|c|c|c|c|}
\hline Amino acid & ME & ME-ALP & ME-PRH & ME-APH \\
\hline Histidine & 4.69 & 3.94 & 4.45 & 4.15 \\
\hline Arginine & 4.41 & 5.01 & 4.98 & 5.24 \\
\hline Threonine & 6.75 & 5.76 & 5.64 & 5.95 \\
\hline Methionine & 1.88 & 4.28 & 3.73 & 4.05 \\
\hline Isoleucine $e^{1)}$ & 2.27 & 6.75 & 6.52 & 6.53 \\
\hline Leucine $^{1)}$ & 4.79 & 11.02 & 11.02 & 10.68 \\
\hline Phenylalanine $^{1)}$ & 1.26 & 4.98 & 5.21 & 4.92 \\
\hline Tryptophan ${ }^{1)}$ & 0.00 & 0.00 & 0.00 & 0.00 \\
\hline Lysine & 6.21 & 8.92 & 10.22 & 8.52 \\
\hline Valine $^{1)}$ & 2.75 & 7.73 & 7.37 & 7.67 \\
\hline Cysteine / cystine & 0.00 & 0.00 & 0.00 & 0.00 \\
\hline $\begin{array}{l}\text { Glutamine / } \\
\text { glutamic acid }\end{array}$ & 9.44 & 8.28 & 8.45 & 8.74 \\
\hline $\begin{array}{l}\text { Aspartic acid / } \\
\text { asparagine }\end{array}$ & 6.08 & 3.12 & 3.10 & 3.03 \\
\hline Serine & 2.93 & 3.28 & 3.03 & 3.40 \\
\hline Glycine & 23.98 & 8.46 & 8.55 & 8.70 \\
\hline Alanine & 12.83 & 8.56 & 7.93 & 8.19 \\
\hline Proline $^{1)}$ & 8.81 & 6.52 & 6.60 & 6.75 \\
\hline Tyrosine $^{1)}$ & 0.93 & 3.40 & 3.20 & 3.49 \\
\hline Total amino acid & 100.00 & 100.00 & 100.00 & 100.00 \\
\hline $\begin{array}{l}\text { Sum of hydrophobic } \\
\text { amino acids }\end{array}$ & 20.81 & 40.40 & 39.92 & 40.04 \\
\hline
\end{tabular}

${ }^{1)}$ Hydrophobic amino acids. amino acids for the ME-ALP, ME-PRH, and ME-APH were $0.404,0.3992$, and 0.4004 , respectively, indicating the hydrophobic amino acids on three hydrolysates of Eastern eel were released via enzymatic hydrolysis.

\section{Discussion}

The eels were considered as a nutritious and tasty species, and as an oriental medicine (Khanh and Ngan, 2010). Especially in Korea and Japan, eels were thought to boost stamina in hot weather, and therefore they have been consumed as the various forms including hot water extracts. Recently, fish protein hydrolysates are widely focused as the main source of bioactive peptides for various health benefits. In this study, to evaluate the health benefits of Eastern eel extracts and hydrolysate, the antioxidative and ACE inhibiting effects of them were compared.

An efficient way of assessing antioxidative activity of eel extracts and hydrolysates is to examine the ability to trap the free radicals produced in various multiple reactions. The radical system used for evaluation of antioxidative activity may influence the experimental result, because of differences in the mechanism of antioxidative action being measured or the reaction conditions used. Therefore, two or more radical systems are required to investigate radical scavenging capacities ( $\mathrm{Yu}$ et al., 2002). A range of assays, including DPPH, ABTS, $\mathrm{O}_{2}^{-}, \cdot \mathrm{OH}$, and $\mathrm{H}_{2} \mathrm{O}_{2}$ scavenging activities, were performed to assess the antioxidative activities of the 
eel extracts and hydrolysates. These trapping techniques measure the radical scavenging activities of samples against free radicals such as DPPH, ABTS, $\mathrm{O}_{2}^{-}, \cdot \mathrm{OH}$, and $\mathrm{H}_{2} \mathrm{O}_{2}$.

DPPH is a stable free radical molecule that changes color from deep violet to colorless or pale yellow on reduction by either hydrogen or electron donation. Substances that can donate hydrogen or electrons are considered to have antioxidative activity. The blue/green $\mathrm{ABTS}^{++}$radical cation produced through the reaction between ABTS and potassium persulfate is converted to a colorless neutral form by a reaction with antioxidants (Carocho and Ferreira, 2013). $\mathrm{O}_{2}{ }^{-}$ is normally formed during the first step of a cellular oxidation reaction, and its effect can be magnified as it produces other kinds of cell-damaging free radicals and oxidizing agents (Liu and $\mathrm{Ng}, 2000$ ). $• \mathrm{OH}$ is the neutral form of the hydroxide ion $\left(\mathrm{OH}^{-}\right)$and the most ROS in biological systems. This radical can damage all types of macromolecules, including carbohydrates, nucleic acids, lipids, and amino acids, and it has the strongest cell-damaging action among free radicals (Chung et al., 1997; Liu and Ng, 2000). In addition, this radical combine with the nucleotides in DNA and cause strand breakage, leading to carcinogenesis, mutagenesis, and cytotoxicity (Khan et al., 2012). $\mathrm{H}_{2} \mathrm{O}_{2}$ is a non-reactive but unstable molecule. Sometimes it is converted to free $\mathrm{OH}^{-}$radicals, which react with the proteins, membrane lipids, and DNA in living cells and cause tissue damage and cell death (Khan et al., 2012).

In our present study, the antioxidative activities of the eel hydrolysates were higher than those of extracts in all types of antioxidative assay systems. These results are in line with Slizyte et al.'s report (2016), showing that the fish protein hydrolysates from defatted salmon backbones obtained with commercial enzymes increased the antioxidative DPPH radical scavenging ability by $10-25 \%$ compared to those without hydrolysis. Among eel hydrolysates, especially the eel hydrolysate treated with Protamex (ME-PRH) exhibited the highest ABTS, $\cdot \mathrm{OH}$, and $\mathrm{H}_{2} \mathrm{O}_{2}$ scavenging activities, indicating ME-PRH could be potential anti-oxidant against free radicals with the strong cell-damaging action.

ACE is a dipeptidyl carboxypeptidase (EC. 3.4.15.1) that was originally isolated from horse blood. It exists as a membrane-bound enzyme as well as a circulatory or globular enzyme (Ortiz-Salmeron et al., 1998). In the renin-angiotensin system, renin promotes the hydrolysis of angiotensin to the decapeptide angiotensin I and ACE hydrolyzes the dipeptide His-Leu at the C-terminus of angiotensin I to produce active angiotensin II, which has a vasoconstricting action. In addition, ACE hydrolyzes and inactivates the vasodilator bradykinin (Das and Soffer, 1975). Therefore, the inhibition of ACE will prevent the production of angiotensin II and inhibit the hydrolysis of bradykinin, which will be useful for controlling high blood pressure and hypertension. In fact, ACE inhibitors are used to treat myocardial infraction, hypertension, and other cardio-related diseases. However, most ACE inhibitors are synthetic, and these drugs have certain adverse side effects (Raghavan and Kristinsson, 2009). Therefore, a number of studies have been conducted to find ACE inhibitors from natural resources, including food protein hydrolysates; the most useful natural ACE inhibitors were found to be peptides from protein hydrolysates (Iwaniak et al., 2014). Sila et al. (2013) recorded $87 \%$ ACE inhibition activity for an Alcalase ${ }^{\circledR}$ hydrolysate from the muscle of Barbel (Barbuscallensis), and Athukorala and Jeon (2005) recorded $85 \%$ for Alcalase ${ }^{\circledR}$ and $74 \%$ for Promatex ${ }^{\circledR}$ hydrolysates of different algal species. In our results, the measurements were very high ( $>$ $70 \%$ ). The $\mathrm{IC}_{50}$ values for the ME-ALP, ME-PRH, and ME-APH were 132.91， 110.37, and $115.17 \mu \mathrm{g} / \mathrm{mL}$, respectively. In Coscueta et al. (2016)'s reports, the potential antihypertensive peptides from milk and soy derived protein hydrolysates showed the $\mathrm{IC}_{50}$ values of $33-930 \mu \mathrm{g} / \mathrm{mL}$, corresponding to the range of eel hydrolysates. In addition, Karaki et al. (1990) reported the anti-hypertensive effect in hypertensive rats using a casein hydrolysate with $\mathrm{IC}_{50}$ value of $166 \mu \mathrm{g} / \mathrm{mL}$. The standard ACE inhibition peptides, Val-Trp and Ala-Tyr, were reported to have the ACE inhibition activity with $\mathrm{IC}_{50}$ value of $200-900 \mu \mathrm{g} / \mathrm{mL}$ (Sato et al., 2002, Slizyte et al., 2016). Baharuddin et al. (2016) reported the ACE inhibitory activity of eel (Monopterus sp.) protein hydrolysate with $\mathrm{IC}_{50}$ value of $2.128 \mathrm{mg} / \mathrm{mL}$ at $\mathrm{DH}$ $36 \%$. These results were rather lower than ACE inhibition activities of Eastern eel hydrolysates treated with Alcalase ${ }^{\circledR}$, Protame ${ }^{\circledR}$, and their mixture in this study, confirming that enzymatic hydrolysates of Eastern eel (A. japonica) could be excellent natural source for ACE inhibitor candidates.

Generally, it has been demonstrated that the biological activities of proteins can be increased via hydrolysis with various enzymes (Chen et al., 1995). During hydrolysis, 
native proteins are cleaved by enzymes, and hidden hydrophobic sites inside the proteins are exposed. These exposed hydrophobic amino acid residues in the peptides obtained confer various biological activities, especially antioxidative and ACE inhibitory activities (Faithong et al., 2010). Additionally, the biological activities of protein hydrolysates depend on the protein substrate, the specificity of the enzyme, the conditions used during proteolysis, and the degree of hydrolysis (Sila et al., 2013). Elavarasan et al. (2014) reported that protein hydrolysates differ in their antioxidant properties based on the nature of the proteases used as the sequence of released peptides are different chiefly based on the type of enzyme used for cleavage. Protein hydrolysates produced by different enzymes have different-sized peptides and amino acid sequences, which can have significantly different biological activities (Centenaro et al., 2011). In this study, the observed antioxidative and ACE inhibitory activities may be related to the enzyme used and each hydrolysate's composition. Alcalase ${ }^{\circledR}$ is a serine alkaline endoprotease with broad specificity; it hydrolyzes most peptide bonds, but preferentially those containing aromatic amino acid residues (Doucet et al., 2003). Promatex ${ }^{\circledR}$ is also an endopeptidase with broad specificity for hydrophobic amino acids (Ward, 1983). Therefore, each hydrolysate produced by theses enzymes may produce various hydrophobic peptides, which might stabilize radicals and inhibit ACE. Actually, Table 2 shows that hydrophobic amino acid contents on three hydrolysates of Eastern eel were higher than on meat extract, indicating the release of hydrophobic peptides via enzymatic hydrolysis. However, additional investigations are required to obtain more information about the amino acid sequences of the active peptides.

Collectively, the enzymatic hydrolysates of Eastern eel ( $A$. japonica) by Alcalase ${ }^{\circledR}$ and Promatex ${ }^{\circledR}$ could be excellent natural source for antioxidant and ACE inhibitor candidates.

\section{요 약}

본 연구는 민물장어의 생리활성을 확인하기 위해 민물장 어 열수추출물과 효소가수분해물을 제조하여 항산화 활성과 $\mathrm{ACE}$ 저해 활성을 비교하였다. 항산화 활성은 다양한 형태의 라디컬인 DPPH, ABTS, $\mathrm{O}_{2}^{-}, \cdot \mathrm{OH}$, and $\mathrm{H}_{2} \mathrm{O}_{2}$ 등에 대한 소거 능으로 비교하였다. 연구결과, 민물장어 추출물은 단백질 수
율 및 항산화 활성 및 $\mathrm{ACE}$ 저해활성이 효소 가수분해물에 비해 대체적으로 낮았다. Alcalase ${ }^{\circledR}$ 가수분해물은 DPPH 라 디컬 소거능이 가장 뛰어났으며, $\mathrm{IC}_{50}$ 값은 $3.02 \mathrm{mg} / \mathrm{mL}$ 였다. 반면 ABTS, $\cdot \mathrm{OH}$, and $\mathrm{H}_{2} \mathrm{O}_{2}$ 등에 대한 소거능은 Protamex ${ }^{\circledR}$ 가수분해물이 가장 높게 나타났으며, 그 $\mathrm{IC}_{50}$ 값은 각각 1.13 $\mathrm{mg} / \mathrm{mL}, 1.30 \mathrm{mg} / \mathrm{mL}, 1.11 \mathrm{mg} / \mathrm{mL}$ 이었다. 민물장어 가수분해 물의 $\mathrm{ACE}$ 저해활성도 대단히 높게 나타났으며, Protamex ${ }^{\circledR}$ 가수분해물의 경우 $\mathrm{IC}_{50}$ 값이 $110.37 \mu \mathrm{g} / \mathrm{mL}$ 였으며, 기존에 보 고된 다양한 가수분해물의 저해활성에 비해 매우 높은 $\mathrm{ACE}$ 저해 활성을 보였다. 이상의 결과에서 민물장어 효소가수분 해물은 항산화제와 $\mathrm{ACE}$ 저해제로 노화를 방지하고 혈압을 감소시킬 수 있는 생리기능성을 가진 식품 소재로서의 가능 성을 보였다.

\section{Conflict of interests}

The authors declare no potential conflict of interest.

\section{ORCID}

Bethelehem Abebe https://orcid.org/0000-0003-2931-2449

Mi-Ryung Kim https://orcid.org/0000-0003-3294-4199

\section{References}

AOAC. Official Methods of Analysis. 18th ed, Association of Official Analytical Chemists, Arlington, VA, USA, Methods 930.15 and 942.05 (2005)

Ahn JC, Chong WS, Na JH, Yun HB, Shin KJ, Lee KW, Park JT. An evaluation of major nutrients of four farmed freshwater eel species (Anguilla japonica, A. rostrata, A. bicolor pacifica and A. marmorata). Kor J Fish Aquat Sci, 48, 44-50 (2015)

Athukorala Y, Jeon YJ. Screening for angiotensin I-converting enzyme inhibitory activity of Ecklonia cava. J Food Sci Nutr, 10, 134-139 (2005)

Azemi WAWM, Samsudin NA, Halim NRA, Sarbon NM. Bioactivity of enzymatically prepared eel (Monopterus sp.) protein hydrolysate at different molecular weights. Int Food Res J, 24, 571-578 (2017)

Baharuddin NA, Halim NRA, Sarbon NM. Effect of degree of hydrolysis (DH) on the functional properties and angiotensin I-converting enzyme (ACE) inhibitory activity of eel (Monopterus sp.) protein hydrolysate. Int Food 
Res J, 23, 1424-1431 (2016)

Binsan W, Benjakul S, Visessanguan W, Roytrakul S, Tanaka M, Kishimura H. Antioxidative activity of Mungoong, an extract paste, from the cephalothorax of White shrimp (Litopenaeus vannamei). Food Chem, 106, 185-193 (2008)

Bougatef A, Nedjar-Arroume N, Manni L, Ravallec R, Barkia A, Guillochon D, Nasri M. Purification and identification of novel antioxidant peptides from enzymatic hydrolysates of sardinelle (Sardinella aurita) by-products proteins. Food Chem, 118, 559-565 (2010)

Carocho M, Ferreira ICFR. A review on antioxidants, prooxidants and related controversy: Natural and synthetic compounds, screening and analysis methodologies and future perspectives. Food Chem Toxicol, 51, 15-25 (2013)

Centenaro GS, Mellado MS, Prentice-Hernandez C. Antioxidant activity of protein hydrolysates of fish and chicken bones. Adv J Food Sci Technol, 3, 280-288 (2011)

Chen HM, Muramoto K, Yamauchi F. Structural analysis of antioxidative peptides from soybean $\beta$-conglycinin. $\mathrm{J}$ Agric Food Chem, 43, 574-578 (1995)

Chung SK, Osawa T, Kawakishi, S. Hydroxyl radicalscavenging effects of spices and scavengers from brown mustard (Brassica nigra). Biosci Biotech Biochem, 61, 118-123 (1997)

Clarke G, Ting KN, Wiart C, Fry J. High correlation of 2,2-diphenyl-1-picrylhydrazyl (DPPH) radical scavenging, ferric reducing activity potential and total phenolic content indicates redundancy in use of all three assays to screen for antioxidant activity of extracts of plants from the Malaysian rainforest. Antioxidants, 2, 1-10 (2013)

Coscueta ER, Amorim MM, Voss GB, Nerli BB, Pico GA, Pintado ME. Bioactive properties of peptides obtained from Argentinian defatted soy flour protein by Corolase PP hydrolysis. Food Chem, 198, 36-44 (2016)

Cushman DW, Cheung HS. Spectrophotometric assay and properties of the angiotensin I-converting enzyme of rabbit lung. Biochem Pharmacol, 20, 1637-1648 (1971)

Darewicz M, Borawska J, Vegarud GE, Minkiewicz P, Iwaniak A. Angiotensin I-converting enzyme (ACE) inhibitory activity and ACE inhibitory peptides of salmon (Salmo salar) protein hydrolysates obtained by human and porcine gastrointestinal enzymes. Int $\mathrm{J}$ Mol Sci, 15, 14077-14101 (2014)

Das M, Soffer RL. Pulmonary angiotensin converting enzyme. Structural and catalytic properties. J Biol Chem, 250, 6762-6768 (1975)

Doucet D, Otter DE, Gauthier SF, Foegeding EA. Enzymeinduced gelation of extensively hydrolyzed whey proteins by alcalase: Peptide identification and determination of enzyme specificity. J Agric Food Chem, 51, 6300-6308 (2003)

Ekanayake PM, Park GT, Lee YD, Kim SJ, Jeong SC, Lee J. Antioxidant potential of eel (Anguilla japonica and Conger myriaster) flesh and skin. J Food lipids, 12, 34-47 (2005)

Elavarasan K, Kumar VN, Shamasundar BA. Antioxidant and functional properties of fish protein hydrolysates from fresh water carp (Catlacatla) as influenced by the nature of enzyme. J Food Process Preserv, 38, 12071214 (2014)

Faithong N, Benjakul S, Phatcharat S, Binsan W. Chemical composition and antioxidative activity of Thai traditional fermented shrimp and krill products. Food Chem, 119, 133-140 (2010)

Food and Agricultural Organization of the United Nations. The state of world fisheries and aquaculture. Rome. In: FAO Fisheries and Aquaculture Department [online] (2012)

FitzGerald RJ, Murray BA, Walsh DJ. Hypotensive peptides from milk proteins. J Nutr, 134, 980S-988S (2004)

Ghanbari R, Zarei M, Ebrahimpour A, Abdul-Hamid A, Ismail A, Saari N. Angiotensin-I converting enzyme (ACE) inhibitory and anti-oxidant activities of sea cucumber (Actinopyga lecanora) hydrolysates. Int J Mol Sci, 16, 28870-28885 (2015)

Halim NRA, Azlan A, Yusof HM, Sarbon NM. Antioxidant and anticancer activities of enzymatic eel (Monopterus $\mathrm{sp}$ ) protein hydrolysate as influenced by different molecular weight. Biocatal Agric Biotechnol, 16, 10-16 (2018)

Halim NRA, Sarbon NM. A response surface approach on hydrolysis condition of eel (Monopterus Sp.) protein hydrolysate with antioxidant activity. Int Food Res J, 24, 1081-1093 (2017) 
Halim NRA, Yusof HM, Sarbon NM. Functional and bioactive properties of fish protein hydolysates and peptides: A comprehensive review. Trends Food Sci Technol, 51, 24-33 (2016)

Iwaniak A, Minkiewicz P, Darewicz M. Food-originating ACE inhibitors, including antihypertensive peptides, as preventive food components in blood pressure reduction. Compr Rev Food Sci Food Safe, 13, 114-134 (2014)

Jamil NH, Halim NRA, Sarbon NM. Optimization of enzymatic hydrolysis condition and functional properties of eel (Monopterus sp.) protein using response surface methodology (RSM). Int Food Res J, 23, 1-9 (2016)

Karaki H, Doi K, Sugano S, Uchiwa H, Sugai R, Murakami U, Takemoto S. Antihypertensive effect of tryptic hydrolysate of milk casein in spontaneously hypertensive rats. Comp Biochem Physiol C Comp Pharmacol, 96, 367-371 (1990)

Khan RA, Khan MR, Sahreen S, Ahmed M. Evaluation of phenolic contents and antioxidant activity of various solvent extracts of Sonchus asper (L.) Hill. Chem Cent J, 6, 12 (2012)

Khanh NH, Ngan HTB. Current practices of rice field eel Monopterus albus (Zuiew, 1973) culture in Vientnam. Aquaculture Asia Magazine, 15, 26-29 (2010)

Kim SR, Byun HG. The novel angiotensin I converting enzyme inhibitory peptide from rainbow trout muscle hydrolysate. Fish Aquat Sci, 15, 183-190 (2012)

Liu Y, Ng TB. Antioxidative and free radical scavenging activities of selected medicinal herbs. Life Sci, 66, 725735 (2000)

Lowry OH, Rosebrough NJ, Farr AL, Randall RJ. Protein measurement with the Folin phenol reagent. J Biol Chem, 193, 265-275 (1951)

Mandal P, Misra TK, Ghosal M. Free radical scavenging activity of and phytochemical analysis in the leaf and stem of Drymaria diandra Blume. Int J Integr Biol, 7, 80-84 (2009)

Marklund S, Marklund G. Involvement of the superoxide anion radical in the autoxidation of pyrogallol and a convenient assay for superoxide dismutase. Eur $\mathbf{J}$ Biochem, 47, 469-474(1974)

Muller HE. Detection of hydrogen peroxide produced by microorganisms on ABTS-peroxidase medium. Zentralbl Bakteriol Mikrobiol Hyg, 259, 151-154 (1985)
Ngo DH, VO TS, Ngo DN, Wijesekara I, Kim SK. Biological activities and potential health benefits of bioactive peptides derived from marine organisms. Int $\mathrm{J}$ Biol Macromol, 51, 378-383 (2012)

Ono S. Hosokawa M, Miyashita K, Takahashi K. Isolation of peptides with angiotensin I-converting enzyme inhibitory effect derived from hydrolysate of upstream chum salmon muscle. J Food Sci, 68, 1611-1614 (2003)

Ortiz-Salmeron E, Baron C, Garcia-Fuentes L. Enthalpy of captopril-angiotensin I-converting enzyme binding. FEBS Lett, 435, 219-224 (1998)

Qian ZJ, Je JY, Kim SK. Antihypertensive effect of angiotensin I converting enzyme-inhibitory peptide from hydrolysates of Bigeye tuna dark muscle, Thunnus obesus. J Agric Food Chem, 55, 8398-8403 (2007)

Qin L, Zhu BW, Zhou DY, Wu HT, Tan H, Yang JF, Li DM, Dong XP, Murata Y. Preparation and antioxidant activity of enzymatic hydrolysates from purple sea urchin (Strongylocentrotus nudus) gonad. LWT-Food Sci Technol, 44, 1113-1118 (2011)

Raghavan S, Kristinsson HG. ACE-inhibitory activity of tilapia protein hydrolysates. Food Chem, 117, 582-588 (2009)

Samaranayaka AGP, Kitts DD, Li-Chan ECY. Antioxidative and angiotensin-I-converting enzyme inhibitory potential of a Pacific Hake (Merluccius productus) fish protein haydrolysate subjected to simulated gastrointestinal digestion and Caco-2 cell permeation. J Agric Food Chem, 58, 1535-1542 (2010)

Sato M, Hosokawa T, Yamakuchi T, Nakano T, Muramoto K, Kahara T, Funayama K, Kobayashi A, Nakano T. Angiotensin I-converting enzyme inhibitory peptides derived from Wakame (Undaria pinnatifida) and their antihypertensive effect in spontaneously hypertensive rats. J Agric Food Chem, 50, 6245-6252 (2002)

Schiffrin EL, Touyz RM. From bedside to bench to bedside: Role of renin-angiotensin-aldosterone system in remodeling of resistance arteries in hypertension. Am J Physiol Heart Circ Physiol, 287, H435-H446 (2004)

Seo JS, Choi JH, Seo JH, Ahn TH, Chong WS, Kim SH, Cho HS, Ahn JC. Comparison of major nutrients in eels Angulilla japonica cultured with different formula feeds or at different farms. Fish Aquat Sci, 16, 85-92 (2013) Sila A, Haddar A, Martinez-Alvarez O, Bougatef A. Angio- 
tensin-I-converting enzyme inhibitory and antioxidant activities of protein hydrolysate from muscle of barbel (Barbus callensis). J Chem, 545303 (2013)

Slizyte R, Rommi K, Mozuraityte R, Eck P, Five K, Rustad T. Bioactivities of fish protein hydrolysates from defatted salmon backbones. Biotechnol Rep, 11, 99-109 (2016)

Ward OP. Proteinases. In: Microbial Enzymes and Biotechnology, Fogarty WM (Editor), Elsevier Applied
Science, London, UK, p 251-317 (1983)

Yu L, Haley S, Perret J, Harris M, Wilson J, Qian M. Free radical scavenging properties of wheat extracts. J Agric Food Chem, 50, 1619-1624 (2002)

Zhou DY, Zhu BW, Qiao L, Wu HT, Li DM, Yang JF, Murata Y. In vitro antioxidant activity of enzymatic hydrolysates prepared from abalone (Haliotis discus hannai Ino) viscera. Food Bioprod Process, 90, 148-154 (2012) 